\title{
Effect of Different Pre-Treatment Methods on Reducing Sugar of Rice Substrate to Enhance the Ethanol Yield
}

\author{
O.P. Suryawanshi ${ }^{*}$, D. Khokhar ${ }^{2}$ and S. Patel $^{3}$ \\ ${ }^{1}$ Department of Food Process Engineering, NIT Rourkela, India \\ ${ }^{2}$ Department of Plant Physiology Agricultural Biochemistry Medicinal and Aromatics Plant, \\ AICRP IGKV Raipur, India \\ ${ }^{3}$ Department of Agricultural Processing and Food Engineering, Faculty of Agricultural \\ Engineering and Technology, IGKV Raipur, India \\ *Corresponding author
}

\section{A B S T R A C T}

\begin{tabular}{|l|}
\hline K e y w o r d s \\
Ethanol, Fermentation, \\
$\begin{array}{l}\text { Reducing sugars, } \\
\text { Biochemical reaction, } \\
\text { Broken rice }\end{array}$ \\
\hline Article Info \\
\hline $\begin{array}{l}\text { Accepted: } \\
\text { 24 February } 2018 \\
\text { Available Online: } \\
\text { 10 March } 2018\end{array}$ \\
\hline
\end{tabular}

\section{Introduction}

In the developing countries the use of fossil fuel is increasing that leads to the rapid exhaustion which cannot be renew and leaving some serious environmental problems. To overcome the problems, the contribution of renewable energy is essential as nonrenewable energy sources are limited and expensive. The alternative of the fuel is biofuel that may produce from the decomposition of bio-materials. In general, the starch of biomaterials is breakdowns into the simple
Ethanol production is also known as ethanolic fermentation in which sugars of biomaterials are converted into the ethanol and carbon hydroxide that may called as coproduct of fermentation. In general fermentation is a bio-chemical process where decomposition of biomaterials takes place. During bio-chemical reduction the sugar compounds like sucrose, fructose, glucose and lactose are converted into the ethyl ethanol and $\mathrm{CO}_{2}$ as by product of the fermentation process. The yield of ethanol greatly depends upon the amount of sugar content, conversion rate (fermentation rate), type of culture and and and aerobic condition. In this study the one of the agricultural produce i.e. broken rice was taken as the source of sugar for ethanol production because it has was prewas pre-treated with different method in order to release the sugars. The more the reducing sugar results higher the ethanol production. 
production by improving the reducing sugar conversion rate. The substrate was pre-treated with sulphuric acid and $\alpha$-amylase enzyme at different concentration for various times. The substrate treated with enzyme gives higher reducing sugars as compare to acid treated substrate. Now days the intention has increasing on use of bioethanol as commercial fuel because of its distinct characteristics like high octane number, lower cetane number and high heat of vaporization. Fermentation is one of the efficient methods for producing biofuels by reducing the biological compounds into ethanol. Fermentation is bio-chemical reaction where degradation of sugar components takes place. Fermentation of biomaterials produces ethanol and carbon dioxide as by product. Ethanol can be replaced instead of fossil fuels that may call renewable energy sources. The ethanol can be produce by fermenting the bio-materials. Basically, the in fermentation the sugar compounds are anaerobically reduced down into ethyl ethanol with the help of fermenting microbes. The yield of ethanol production mainly depends upon the amount of free sugar that is available for chemically conversion and microorganisms. To increase the production of free sugars and ethanol, different pretreatment may involve before fermentation. Pre-treatments before fermentation may help in converting the complex sugar into the simple sugar by releasing the free sugars. Different pre-treatment like sulphuric acid and enzymatic reaction may perform to increase the ethanol production and thereby to produce an alternative fuel to replace the fossil fuels. From the last few decades, the production of bio-ethanol by fermentation has taken attention. An association has been surveyed that United States and Brazil are the world's top most lading countries at global level ethanol production i.e. approximately $90 \%$ (Demirbas, 2009). Now the days the other countries are too started the commercializing the ethanol production from the biomaterials
(Sims, Mabee et al., 2010). In North America, the ethanol are producing by using mainly corn starch while in South America sugarcane straws, molasses and juices are using as feed materials for ethanol production (Spyridon, Euverink et al., 2016). Fermentation depends mainly on the biochemical process where starch gets converted into the simple sugars. But the chemical reaction of starch to simple sugar may involves the basically two process as saccharification, where starch is converted into sugar using an amylolytic microorganism or enzymes such as $\alpha$-amylase and another is fermentation, where sugar is converted into ethanol using Saccharomyces cerevisiae (Inlow et al., 1988). The aim of this study is to determine the effect of various pre-treatments on yield of ethanol production.

\section{Materials and Methods}

\section{Selection and procurement of substrate}

The commonly summer grown rice varieties (viz. IR-36, IR-64, MTU-1010, Danteshwari, Mahamaya HMT, and Javafull etc.) of the Chhattisgarh state collected from the Department of Genetics and Plant Breeding, College of Agriculture, Indira Gandhi Krishi Vishwavidyalaya, Raipur. The broken rice percentage was determined by availing the lab scale milling facilities available in Department of Genetics and Plant Breeding. After determination of broken percentage of rice varieties, the four rice varieties namely as: IR36, IR-64, MTU-1010 and Danteshwari were selected for the study.

\section{Preparation of the substrate}

A known quantity $(50 \mathrm{gm})$ of each rice variety (IR-36, IR-64, MTU-1010 and Danteshwari) was steep for one hour and cooked separately in aluminum cooker having 1Ltr. Capacity with equal amount of water (W/V) up to 5 min after one whistle on sim mode. After cooling 
of the cooked rice, paste was prepared using pastel mortar. Further, $25 \mathrm{gm}$ of the mashed (paste) substrate weighed separately and volume was made to $35 \mathrm{ml}$ with distilled water for the hydrolysis of fermentable sugars.

\section{Acid pre-treatment}

The mashed substrate was pre-treated with 25 $\mathrm{ml}$ sulphuric acid (Plate 3.2) at different concentrations viz., 0.5, 1.0, 2.0 and 2.5 per cent and kept at different incubation periods viz., $2,4,8$, and 24 hours at $28 \pm 2{ }^{\circ} \mathrm{C}$ for hydrolysis of fermentable sugars.

\section{Enzyme pre-treatment}

Commercial $\alpha$-amylase (Diastase $\alpha$-amylase) enzyme was prepared with buffer, $10 \mathrm{mM}$ $\mathrm{CaCl}_{2}$ at different concentration viz., 0.5, 1.0 and 2.0 per cent and added to the mashed substrate for saccharification.

\section{Estimation of reducing sugars}

The reducing sugars were estimated (Plate 3.3) by following 3, 5, Dinitrosalicylic acid method (Miller, 1959).

\section{Preparation of reagents}

\section{DNSA}

One gram of 3,5, Dinitrosalicylic acid (DNSA), $200 \mathrm{mg}$ of crystal phenol and $50 \mathrm{mg}$ of sodium sulphite was dissolved in $1.0 \% \mathrm{NaOH}$ solution and the volume was made up to $100 \mathrm{ml}$ reagent was stored at $4{ }^{\circ} \mathrm{C}$. Since the reagent deteriorates during long storage due to sodium sulphite; hence, sodium sulphite was added at the time of use.

\section{Rochelle salt solution $40 \%$}

Rochelle salt solution was prepared by dissolving $40 \mathrm{~g}$ of potassium sodium tartarate in distilled water and volume was made up to $100 \mathrm{ml}$.

\section{Preparation of stock solution of glucose}

Standard stock solution of glucose was prepared at $1 \mathrm{mg} / \mathrm{ml}$ by dissolving $100 \mathrm{mg}$ of D-glucose in distilled water and final volume was made upto $100 \mathrm{ml}$.

\section{Procedure}

Sample of $0.5 \mathrm{ml}$ from acid pre-treated and 0.1 $\mathrm{ml}$ from enzymatic pre-treated hydrolysed sample was drawn from each treatment and delivered into thin walled test tubes and volume was made to $1.0 \mathrm{ml}$ with distilled water. The reagent blank containing $1 \mathrm{ml}$ of distilled water was also kept. Similarly, standards were also included ranging from 0.1 $\mathrm{mg}$ to $1.0 \mathrm{mg} / \mathrm{ml}$ of glucose. $0.5 \mathrm{ml}$ of DNSA reagent was added to each sample, mixed well and kept on boiling water bath for $5 \mathrm{~min}$. The sample was added with $1 \mathrm{ml}$ of 40 per cent Rochelle salt solution before cooling and volume was made upto $25 \mathrm{ml}$ using volumetric flask.

Absorbance in terms of optical density of the standard and the sample were recorded at 510 $\mathrm{nm}$ using visible spectrophotometer-106 (Plate 3 ). The standard curve of glucose was plotted on graph (Fig. 4).

\section{Estimation of starch}

The starch was estimated by anthrone method (Hodge and Hofreiter, 1962).

\section{Preparation of Reagents}

\section{Anthrone reagent}

Two hundred $\mathrm{mg}$ of anthrone powder was dissolved in $100 \mathrm{ml}$ of ice cold 95 per cent sulphuric acid. 


\section{Preparation of stock solution of glucose}

Standard stock solution was prepared by dissolving $10 \mathrm{mg}$ of $\mathrm{D}$-glucose in distilled water and final volume was made upto $10 \mathrm{ml}$ with distilled water.

\section{Procedure}

Homogenize well-grounded rice sample of 0.5 $\mathrm{g}$ in hot $80 \%$ ethanol to remove sugars. Centrifuge and retain the residue repeatedly with hot $80 \%$ ethanol till the washing does not give color with anthrone reagent. To the residue add $0.5 \mathrm{ml}$ of water and $6.5 \mathrm{ml}$ of $52 \%$ perchloric acid. Extract at $60^{\circ} \mathrm{C}$ for $20 \mathrm{~min}$. Centrifuge and collect the supernatant. Repeat the extraction using fresh perchloric acid. Centrifuge and collect the all the supernatant and makeup upto $100 \mathrm{ml}$. Pipette out the 0.2 $\mathrm{ml}$ of the supernatant and make up the volume to $1 \mathrm{ml}$ with water. Prepare the glucose standard by taking $0.2,0.4,0.6,0.8$ and $1 \mathrm{ml}$ of standard solution of glucose. Add $4 \mathrm{ml}$ of anthrone reagent to each tube. Heat the sample for eight minutes in boiling water bath. The samples were cooled rapidly and the colour intensity of the standards and the samples were recorded as $630 \mathrm{~nm}$ using visible spectrophotometer-106. The standard curve of glucose was plotted on graph (Fig. 5).

\section{Fermentation}

After hydrolysis of samples volume was made up upto $100 \mathrm{ml}$ for fermentation. The hydrolysate from the pre-treatment was ameliorated to obtain $24^{\circ}$ Brix by adding cane sugar. Brix reading of the samples was determined with the help of hand refractometer having a range of $0-32^{\circ} \mathrm{Brix}$ at $20^{\circ} \mathrm{C}$ and $\mathrm{pH}$ was adjusted to 3.5 by adding sodium bicarbonate. Activity of the natural flora of the must was suppressed by adding $200 \mathrm{mg}$ of potassium metabisulphite and kept for 4-5 hours. The must was supplemented with diammonium hydrogen phosphate $(0.5$ $\mathrm{g} / \mathrm{l}$ ) as a source of nitrogen and phosphorus.

The pretreated samples $(100 \mathrm{ml})$ of rice varieties were inoculated with standard yeast, Saccharomyces cerevisiae 3281, Saccharomyces cerevisiae 3570 and Saccharomyces cerevisiae 3640 @ 5 per cent. The samples were fermented anaerobically at $28 \pm 1^{\circ} \mathrm{C}$ in incubator at $90 \mathrm{rpm}$.

\section{Estimation of ethanol}

The ethanol was estimated by colorimetric method as described by Caputi et al., (1968).

\section{Preparation of reagent}

\section{Potassium dichromate solution}

Thirty-four grams of $\mathrm{K}_{2} \mathrm{Cr}_{2} \mathrm{O}_{7}$ was dissolved in $500 \mathrm{ml}$ distilled water, $325 \mathrm{ml}$ of sulphuric acid was added to it slowly and volume was made up to $1000 \mathrm{ml}$ with distilled water to give $0.23 \mathrm{~N} \mathrm{~K}_{2} \mathrm{Cr}_{2} \mathrm{O}_{7}$.

\section{Preparation of standard ethanol solution}

Standard ethanol solution was prepared by dissolving $12.67 \mathrm{ml}$ of 100 per cent pure analytical grade (containing $789 \mathrm{mg} / \mathrm{ml}$ ) ethanol in $100 \mathrm{ml}$ distilled water, which results in $10 \mathrm{mg} / \mathrm{ml}$ of standard ethanol.

\section{Procedure}

One $\mathrm{ml}$ of representative samples from each treatment was transferred to $250 \mathrm{ml}$ round bottom distillation flask connected to the condenser and was diluted with $30 \mathrm{ml}$ distilled water. The sample was distilled at $74-75^{\circ} \mathrm{C}$. The distillate was collected in $25 \mathrm{ml}$ of $0.23 \mathrm{~N}$ $\mathrm{K}_{2} \mathrm{Cr}_{2} \mathrm{O}_{7}$ reagents, which was kept at receiving end. The distillate containing ethanol was collected till total volume of $45 \mathrm{ml}$ was obtained. Similarly, standards (20-100 mg 
ethanol) were mixed with $25 \mathrm{ml}$ of $\mathrm{K}_{2} \mathrm{Cr}_{2} \mathrm{O}_{7}$ separately and the volume was made up to 45 $\mathrm{ml}$. The distillate of samples and standards were heated in water bath at $60^{\circ} \mathrm{C}$ for 20 minutes and cooled. The volume was made upto $50 \mathrm{ml}$ with distilled water and the optical density was measured at $600 \mathrm{~nm}$ using visiblespectrophotometer-106. The standard curve was plotted considering the concentration against absorbance.

\section{Results and Discussion}

Ethanol is a fermented product of cereals, fresh fruits etc. Ethanol from rice is produced after saccharification of starch by acids, enzymes (especially, commercial amylase) etc. Produced raw ethanol is a complex mixture of organic and inorganic substances like carbohydrates, proteins, amino acids, ethyl ethanol, organic acids, inorganic acids and micronutrients etc. The quality/ quantity of ethanol depend on the composition of rice. The ethanol quality differs with rice varieties and also with different yeast strains. The experimental results on screening of rice varieties and microbial cultures, standardization of pre-treatment methods for efficient hydrolysis for release of free sugar, screening of yeast strains for ethanol production and condition optimization are presented in this chapter.

\section{Selected rice varieties}

From the above table the following rice varieties were selected on the basis of higher broken rice percentage (which is higher than normal broken percentage) for further experiments.

Initial starch and protein content of different rice varieties

The data recorded on starch and protein content in different selected varieties of rice are presented in Table 4.3 and Figure 2 (a \& b) the obtained results clearly indicated that rice varieties differed in starch and protein contents. The highest starch content was recorded in IR-36 rice variety which accounts to 84.393 per cent, followed by MTU-1010 $(83.067 \%)$ variety, which did not differ significantly with Danteshwari $(83.067 \%)$ and IR-64 $(83.003 \%)$ varieties. Highest protein content was recorded in IR-64 rice variety (7.997\%) followed by IR-36 variety $(7.370 \%)$ and both were significantly superior over other two rice varieties. Ramarathnam and Kulkarni (1988) and Sadhana Singh et al., (1998) also observed wide variation in starch content (65$72 \%, 61.76 \%-77.95 \%$ ) of 17 and 6 varieties, respectively. Damir (1985) reported that the parboiled and raw rice when milled contained crude protein of8.14 and 7.67, respectively.

\section{Effect of acid and enzyme pre-treatment}

Among the different pre-treatment method acid pre-treatment, microbial pre-treatment using bacterial culture and enzymatic pretreatment used for efficient hydrolysis for ethanol production. In the current study only acid treatment and enzyme treatment was analysed.

\section{Effect of different concentration of acid pre-treatment on reducing sugar content in different rice varsities}

Table 4.4 and Figure 3 indicate that maximum reducing sugar was released in IR-36 ranging from 5.299 to 11.534 with different acid concentration, with the mean 9.618 which is significantly higher in comparison to other rice varieties. On other hand highest (11.452) reducing sugar on mean basis was released in $2.5 \%$ acid treatment; however, 11.435 in $2 \%$ acid treatment was statistically at par.

Starch is a polysaccharide composed of glucose units. Hydrolysis of starch to obtain 
glucose may be carried out either by chemical treatment or by enzyme treatment. In the above experiment rice starch was hydrolysed using various concentration of sulphuric acid. As the concentration of acid is increased the amount of hydrolysed product is increased up to an extent, after that increase in the concentration do not affect the hydrolysis as indicated in results. In the experiment production of free sugar increases significantly up to $2 \%$ acid concentration. From $2-2.5 \%$ acid treatment, production of free sugar increase marginally. On the other hand, production of free glucose also depends on the quality of starch (amylase, amylopactin ratio and degree of polymerization) which differ from variety to variety which is also indicated by the results, as IR -36 produce significant amount of free sugar in comparison to other varieties. Lee et al., (2000) achieved 4 percent sugar solution by pre-treatment of cellulosic biomass with 0.07 per cent sulphuric acid. Geeta et al., (2002) optimized the extraction of soluble reducing sugars from Samaneasaman pods by hot water and acid extraction and observed maximum release of reducing sugars $(313 \mathrm{mg} / \mathrm{g})$ at one per cent acid $\left(\mathrm{H}_{2} \mathrm{SO}_{4}\right)$ concentration.

\section{Effect of commercial $\alpha$-amylase (Diastase $\alpha$ - amylase) on hydrolysis}

An experiment was conducted to know the effect of commercial $\alpha$-amylase pre-treatment on hydrolysis on different rice varieties. Reducing sugar content of rice differed at different incubation periods along with different concentration of $\alpha$ - amylase enzyme viz. $0 \%, 0.5 \%, 1 \%$, and $2 \%$ level.

\section{Effect of enzyme concentration on reducing sugar content at different rice varieties}

Sugar content was highest from 5.269 to $48.237 \mathrm{mg} / \mathrm{g}$ (Table 4.11 and Figure 9) with all the enzyme concentration in IR-36, with the mean 34.135 which is significantly higher in comparison to other rice varieties. On other hand highest $(46.456 \mathrm{mg} / \mathrm{g}$ ) reducing sugar content on mean basis was found in $2 \%$ enzyme concentration; however, $46.365 \mathrm{mg} / \mathrm{g}$ at $6 \mathrm{~h}$ was statistically at par.

The results of the investigation (Table 4.12 and Figure 10) clearly revealed that reducing sugar content in control (zero per cent concentration) was $5.330 \mathrm{mg} / \mathrm{g}$ even at $7 \mathrm{~h}$. Maximum sugar was observed at $7 \mathrm{~h}$ incubation period with $2 \%$ enzyme treatment in IR-36 rice variety. However, sugar content $69.920 \mathrm{mg} / \mathrm{g}$ and $69.952 \mathrm{mg} / \mathrm{g}$ with $1 \%$ enzyme treatment at $6 \mathrm{~h}$ and $7 \mathrm{~h}$ respectively in the same IR-36 rice variety is statistically at par.

Hydrolysis of starch was carried out using enzyme treatment. In the above experiment rice starch was hydrolysed using various concentration of $\alpha$-amylase enzyme. The enzymatic hydrolysis of different biomass depends upon different parameters viz., structural property of the substrate, bonding mode of action for enzyme, adsorption and desorption phenomenon (Sattler et al., 1998). Enzyme digests the starch at faster rate than the acid treatment as revealed from the above results. As the concentration of enzyme is increases the amount of free sugar increases up to a limit, where other factor limits the enzyme activity as shown from the result that sugar content was significantly higher at $1 \%$ enzyme treatment in comparison to $0.5 \%$.

However, the sugar content released by $1 \%$ enzyme was statistically at par to the sugar content at $2 \%$ enzyme treatment. Starch quality also affects the enzyme activity. Similar work was carried out by Aguirre et al., (1978) and they reported that 0.1 per cent of $\alpha$-amylase gives best results when tested on processing of pre-cooked rice and maize flours at different concentration. 
Table.1 Selected rice varieties

\begin{tabular}{l|l|l}
\hline S.N. & Name of the Rice variety & Source \\
\hline 1. & MTU-1010 & I.G.K.V. Raipur \\
2. & IR-36 & I.G.K.V. Raipur \\
3. & IR-64 & I.G.K.V. Raipur \\
4. & Danteshwari & I.G.K.V. Raipur
\end{tabular}

Table.2 Initial starch and protein content in different rice varieties

\begin{tabular}{|l|l|l|l|}
\hline S.N. & Rice varieties & Starch \% & Protein \% \\
\hline $\mathbf{1}$ & MTU-1010 & 83.067 & 7.342 \\
\hline $\mathbf{3}$ & IR-64 & 83.003 & 7.997 \\
\hline 4 & IR-36 & 84.393 & 7.370 \\
\hline & DANTESHWARI & 83.067 & 7.200 \\
\hline
\end{tabular}

Table.3 Interaction table of variety and treatments

\begin{tabular}{|c|c|c|c|c|c|c|}
\hline Variety & $0 \%$ & $0.5 \%$ & $1 \%$ & $2 \%$ & $2.5 \%$ & Mean \\
\hline MTU-1010 & 5.247 & 8.867 & 10.902 & 11.409 & 11.448 & 9.574 \\
\hline IR-64 & 5.270 & 8.890 & 10.882 & 11.414 & 11.390 & 9.569 \\
\hline IR-36 & 5.299 & 8.767 & 10.989 & 11.499 & 11.534 & 9.618 \\
\hline DANTESHWARI & 5.247 & 8.819 & 10.913 & 11.418 & 11.435 & 9.566 \\
\hline Mean & 5.266 & 8.836 & 10.921 & 11.435 & 11.452 & \\
\hline & & & $\begin{array}{r}\text { Acid tr } \\
\text { Int }\end{array}$ & $\begin{array}{l}\text { ariety } \\
\text { itment } \\
\text { action }\end{array}$ & $\begin{array}{l}\text { C.D. } \\
0.020 \\
0.022 \\
0.044\end{array}$ & $\begin{array}{c}\mathrm{SE}(\mathrm{m}) \\
0.007 \\
0.008 \\
0.016\end{array}$ \\
\hline
\end{tabular}

Table.4 Interaction of table variety and enzymatic concentration

\begin{tabular}{|c|c|c|c|c|c|}
\hline Variety & $0 \%$ & $0.5 \%$ & $1 \%$ & $2 \%$ & Mean \\
\hline MTU-1010 & 5.194 & 34.319 & 44.995 & 45.304 & 32.453 \\
\hline IR-64 & 5.240 & 33.842 & 46.477 & 46.420 & 32.995 \\
\hline IR-36 & 5.269 & 34.722 & 48.310 & 48.237 & 34.135 \\
\hline DANTESHWARI & 5.192 & 34.273 & 45.677 & 45.863 & 32.751 \\
\hline Mean & 5.224 & 34.289 & 46.365 & 46.456 & \\
\hline & & & $\begin{array}{r}\text { Variety } \\
\text { etreatment } \\
\text { Interaction }\end{array}$ & $\begin{array}{c}\text { C.D. } \\
0.334 \\
0.334 \\
0.669\end{array}$ & $\begin{array}{c}\mathrm{SE}(\mathrm{m}) \\
0.120 \\
0.120 \\
0.240\end{array}$ \\
\hline
\end{tabular}


Table.5 Interaction table of different culture and rice varieties

\begin{tabular}{|l|c|c|c|c|}
\hline Variety & NCIM 3570 & NCIM 3281 & NCIM 3640 & Mean \\
\hline MTU-1010 & 4.013 & 3.998 & 4.005 & 4.005 \\
\hline IR-64 & 2.766 & 4.038 & 3.781 & 3.862 \\
\hline IR-36 & 4.064 & 4.085 & 4.039 & 4.063 \\
\hline DANTESHWARI & 4.014 & 4.037 & 4.019 & 4.023 \\
\hline \multicolumn{1}{|c|}{ Mean } & 3.964 & 4.039 & 3.961 & \\
\hline & & C.D. & SE(m) \\
& & Curiety & 0.010 & 0.004 \\
& & Interaction & 0.009 & 0.003 \\
& & & 0.006 \\
\hline
\end{tabular}

Table.6 Interaction table of enzyme concentration and rice variety

\begin{tabular}{|c|c|c|c|c|c|}
\hline Variety & C1 & C2 & C3 & C4 & Mean \\
\hline MTU-1010 & 0.495 & 2.982 & 6.257 & 6.286 & 4.005 \\
\hline IR-64 & 0.493 & 2.953 & 6.338 & 5.663 & 3.862 \\
\hline IR-36 & 0.494 & 3.067 & 6.340 & 6.349 & 4.063 \\
\hline DANTESHWARI & 0.492 & 2.982 & 6.294 & 6.325 & 4.023 \\
\hline Mean & 0.494 & 2.996 & 6.307 & 6.156 & \\
\hline & & & Variety & 0.010 & 0.004 \\
& & & Enzyme treatment & 0.010 & 0.003 \\
& & Interaction & 0.021 & 0.007 \\
\hline
\end{tabular}

Table.7 Analysis of variance (ANOVA) table for ethanol production with different cultures and enzymatic treatments in different rice varieties

\begin{tabular}{|l|c|c|c|c|c|}
\hline Source of Variation & DF & Mean squares & F-Cal & C.D. & SE (m) \\
\hline variety (A) & 3 & 0.278 & 566.991 & 0.010 & 0.004 \\
\hline Culture (B) & 2 & 0.096 & 195.964 & 0.009 & 0.003 \\
\hline Int. AxB & 6 & 0.064 & 131.199 & 0.018 & 0.006 \\
\hline Enzyme\% (C) & 3 & 279.276 & 570507.832 & 0.010 & 0.004 \\
\hline Int. AxC & 9 & 0.246 & 502.232 & 0.021 & 0.007 \\
\hline Int. BxC & 6 & 0.071 & 144.124 & 0.018 & 0.006 \\
\hline Int. (AxBxC) & 18 & 0.061 & 124.155 & 0.036 & 0.013 \\
\hline \multicolumn{1}{|r|}{ Error } & 96 & 0.000 & & & \\
\hline Total & 143 & & & & \\
\hline
\end{tabular}

Table.8 Ethanol production at optimized condition

\begin{tabular}{|c|c|c|l|l|l|}
\hline Rice & Sulbstrate concentration & Culture & Temperature & Agitation & Ethanol \% \\
\hline IR-36 & $1: 1$ & NCIM 3281 & $30 \pm 1{ }^{\circ} \mathrm{C}$ & $100 \mathrm{rpm}$ & 6.858 \\
\hline
\end{tabular}


Fig.1 Standard graph for glucose using DNSA method

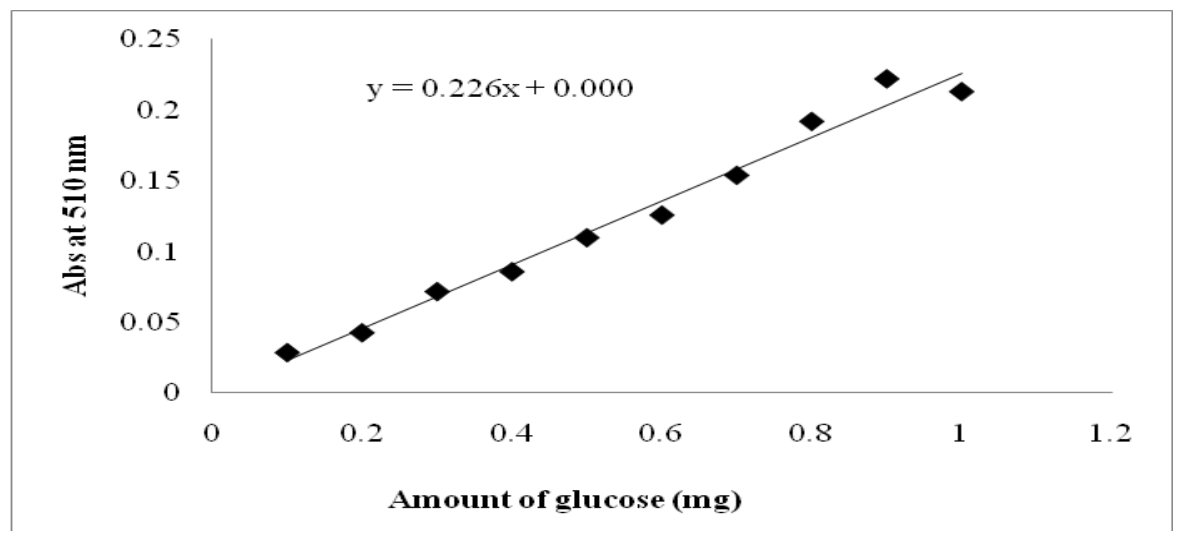

Fig.2 Standard graph of glucose using Anthrone reagent

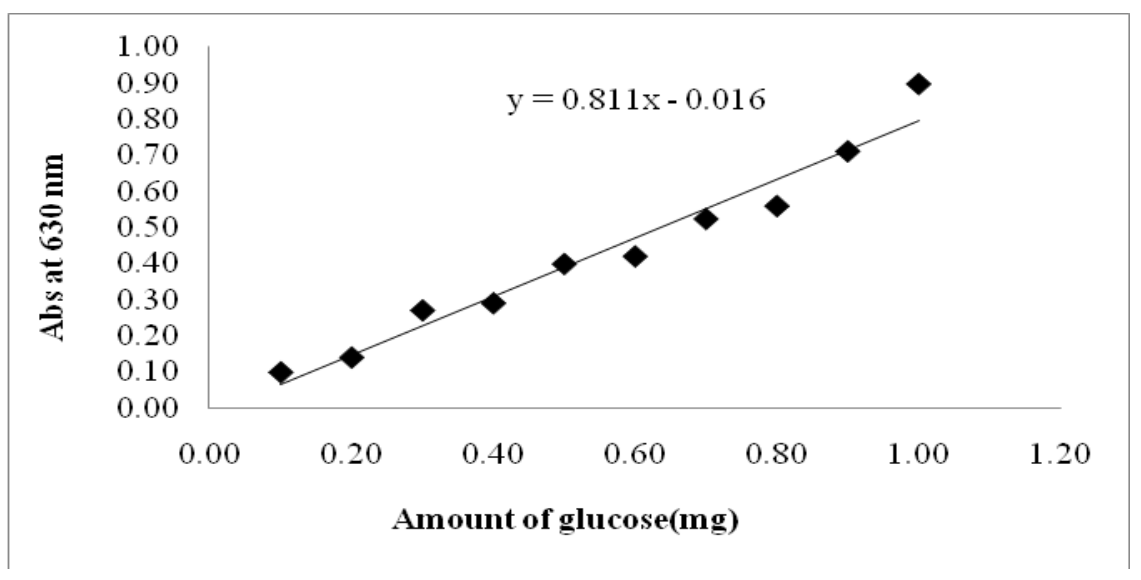

Fig.3 Starch and Protein percentage of selected varieties

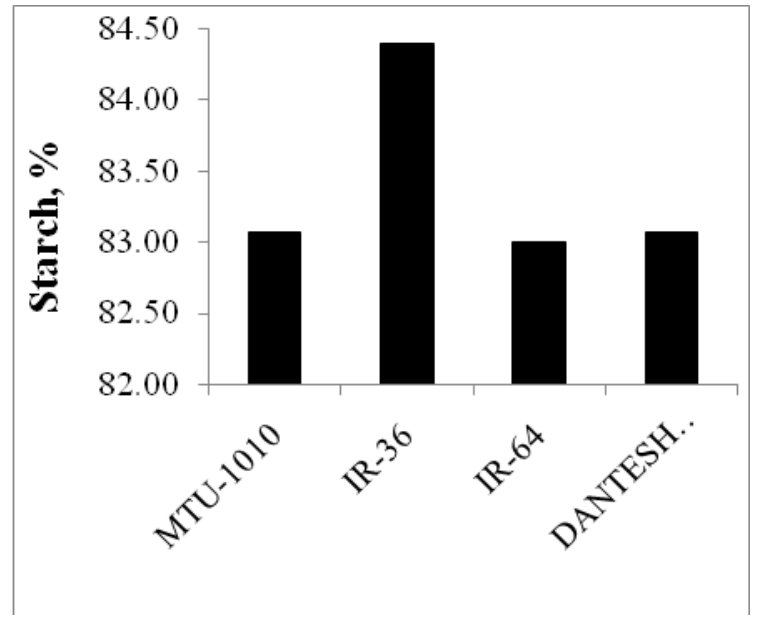

(a)

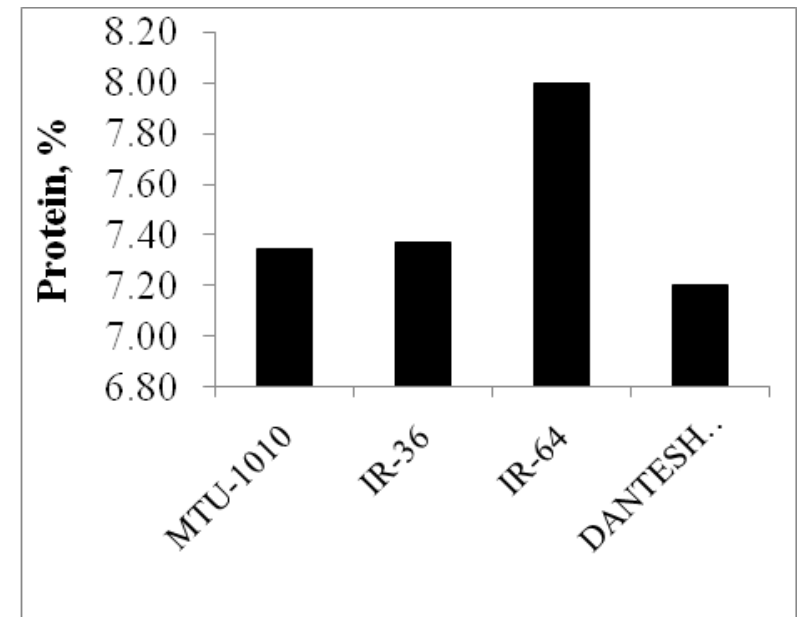

(b) 
Fig.4 Interaction of variety and treatments

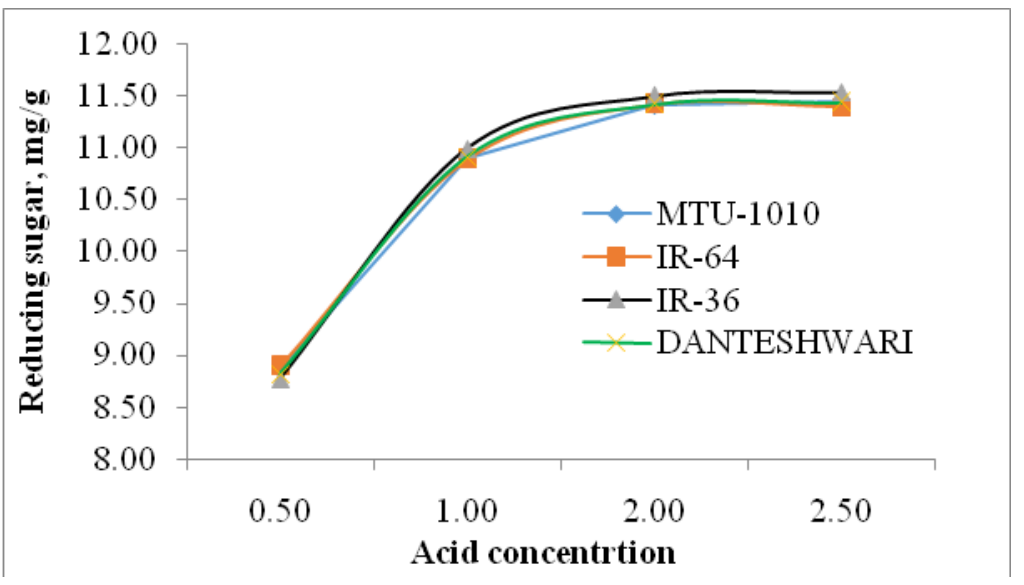

Fig.5 Interaction variety and enzymatic concentration

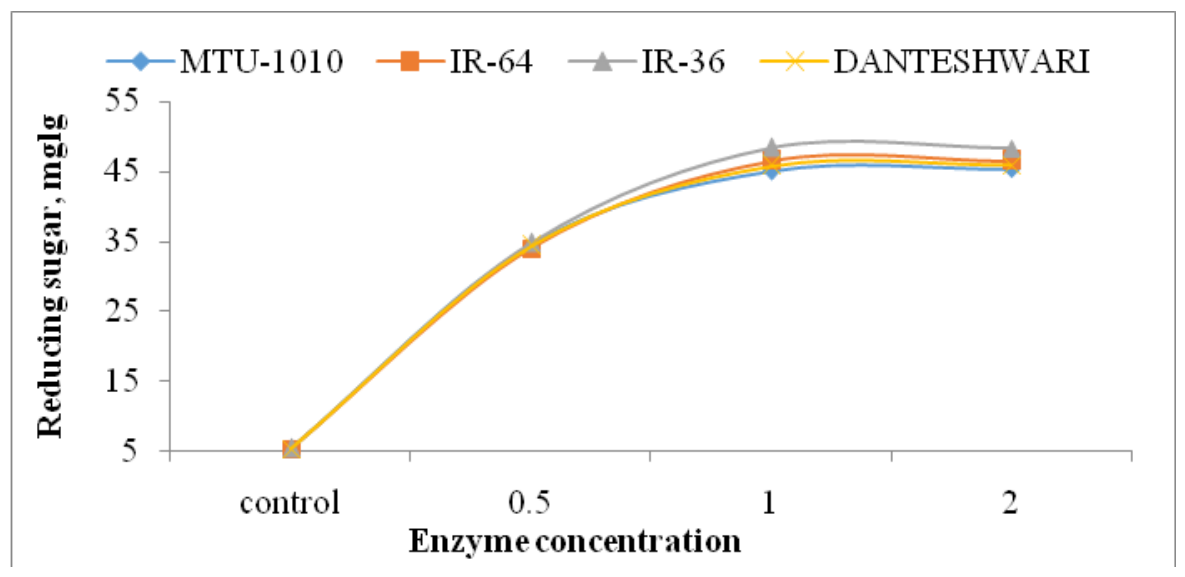

Fig.6 Interaction of different culture and rice varieties

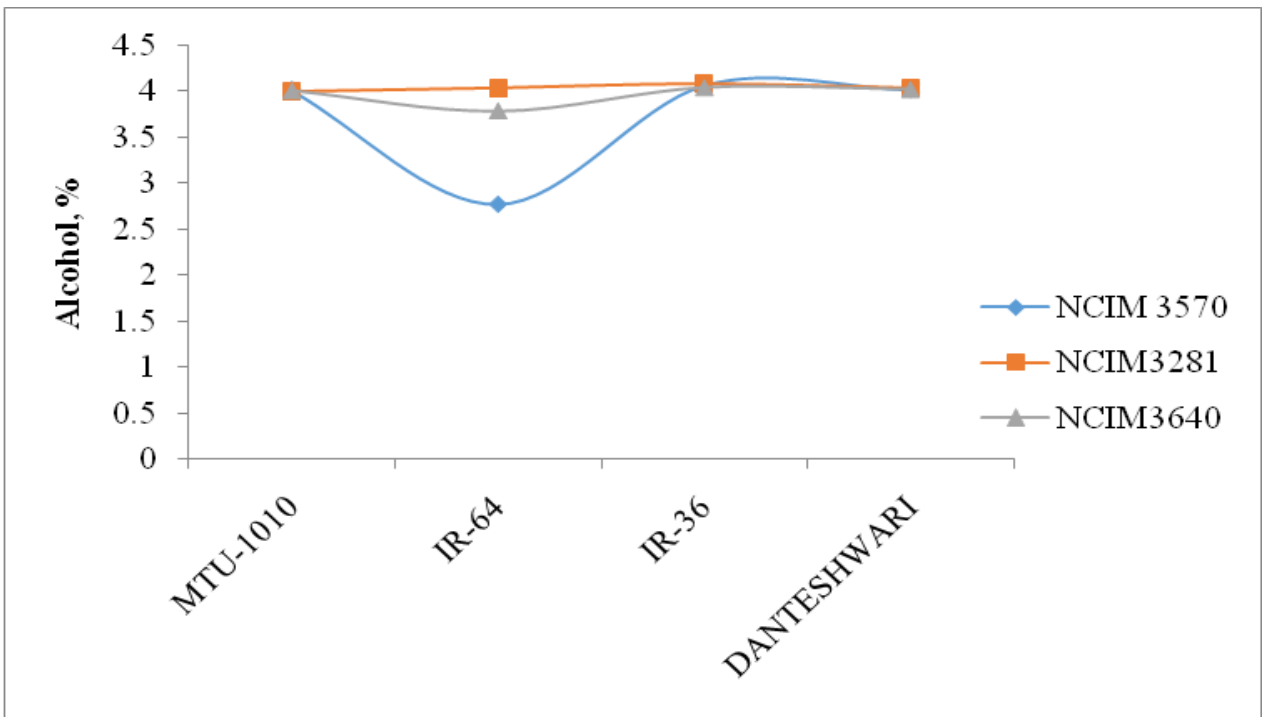


Fig.7 Interaction enzyme concentration and rice variety

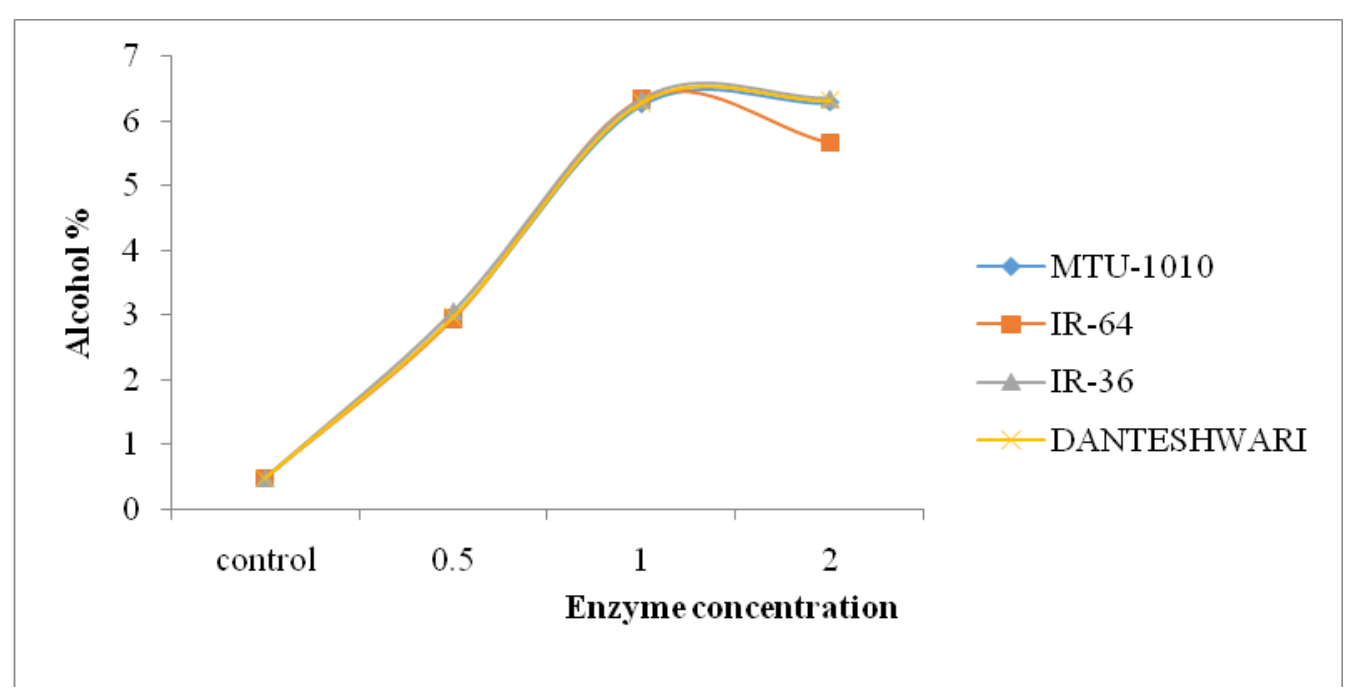

Similarly, Brooks and Griffin (1987) observed maximum reducing sugars for both long and short grain rice varieties at 0.01 per cent (w/v) concentration and $70^{\circ} \mathrm{C}$ temperature. Complex starch (higher percent of amylopactine ratio with higher degree of branching) is less digested by the enzyme. Starch quality differs from variety to variety. Above results also reveals that there is a significant variation in release of free sugar among the varieties. Hence, from the above results it is inferred that reducing sugar was maximum in rice variety IR-36 followed by other rice variety. It was also cleared from the above results that enzyme treatment @ 2\% was better but treatment @1\% was at par. Similarly, the incubation period $7 \mathrm{~h}$ gives highest amount of free sugar; however, 6h was at par.

\section{Ethanol Production}

Saccharomyces cerevisiae strains are known for ethanol production from various carbohydrates containing raw material. In this experiment raw material used for ethanol production was broken rice after pretreatment (various percent of $\alpha$-amylase treatment for $6 \mathrm{~h})$. Pre-treated rice from all the varieties was further incubated with three different yeast strain of Saccharomyces cerevisiae namely: viz. NCIM 3570, NCIM 328 and NCIM 3640 for ethanol production. The ethanol produced after fermentation was analysed using standard method and ethanol content presented on percent basis.

\section{Effect of yeast strain on ethanol production from different varieties}

Table 4.15 and F0igure 4.11 indicate that maximum ethanol production was found in IR-36 ranging from 4.064 to $4.039 \%$ with all three different cultures, with the mean 4.063 which is significantly higher in comparison to other rice varieties, while IR-64 produces least ethanol (3.862\%) on the mean basis. On other hand significantly higher ethanol (4.039) percentage on mean basis was produced with yeast strain NCIM 3281 .

\section{Effect of enzymatic concentration on ethanol production in different rice varieties}

From the Table 4.16 and Figure 4.12 it can be inferred that maximum ethanol production is found in IR-36 ranging from 0.494 to $6.349 \%$ 
with different concentration of enzyme, with the mean $4.063 \%$ which is significantly higher in comparison to other rice varieties. On other side highest ethanol (6.307) percentage on mean basis was observed with pre-treatment of $1 \%$ enzyme concentration for $6 h$.

Effect of enzyme pre-treatment, different cultures and rice varieties on ethanol production

Ethanol is produced by the yeast through fermentation process. Yeast strain differs in their capacity to produce ethanol and ethanol production from the yeast strain also affected by the other factors. In the above experiment three yeast strains were incubated with substrate from four different rice varieties treated at four different enzyme concentrations. From the results of the above experiment it is revealed that rice variety IR36 treated with $1 \% \quad \alpha$-amylase enzyme produce significantly higher ethanol $(6.386 \%)$ with NCIM 3281 strain, while IR-64 produce least amount of ethanol.

Referring the ANOVA (Table 4.19) it was observed that the varieties, enzyme treatment and yeast strain along with their interactions significantly affect the ethanol production at $5 \%$ confidence level.

\section{Ethanol production at optimized conditions}

Ethanol was produced by following all the optimized conditions from IR-36 with $S$. cerevisiae NCIM 3281 and it was recorded $6.858 \%$.

From the above study it seems like the pretreatment of rice substrate by enzyme is more enough to release the reducing sugar from starch. So it can be concluded that the pretreatment with different concentration of enzyme is best for maximum ethanol production as compare to acid pre-treatment From the study it can be concluded that the enzyme concentration of $1 \%$ and hydrolysis time of $6 \mathrm{~h}$ gives the maximum ethanol production.

\section{Acknowledgements}

I would like special thanks to my professors and my friends. I would like to special thanks to my college Faculty of agricultural Engineering and Technology. Also, I would like to give heartily thanks to Department of Plant Physiology Agricultural Biochemistry Medicinal and Aromatics Plant for their kind cooperation, IGKV Raipur C.G.

\section{Conflict of interest}

No conflicts of interest.

\section{Funding sources}

Department Agricultural Processing and Food Engineering, IGKV Raipur

\section{References}

Abate, C., calloeri, D., rodriguez, E. And garro, O., 1996, Ethanol production by a mixed culture of flocculent strains of Zymomonas mobilis and Saccharomyces Sp. Applied Microbiology and Biotechnology, 45: 580-583.

Agu, R. C. and Obanu, Z. A., 1991, Studies on beer production from Nigerian millet. Journal of Food Science and Technology, 28(2): 81-83.

Aguirre, J. M. De, Travaglini, D. A., Pereira, L., Siwacampos, S. D. da, Silveira, E. T. F. and Figuecredo, I. B., 1978, Application of a-amylase in processing of pre-cooked rice and maize flours in a double drum drier. Boletim do Instituto de Technologia de Alimentos, Brazil, 59: 99-116. 
Amerine, M. A. And Ough, C. S., 1980, Wine and Must Analysis, 1-34 Ed. A. Wiley, Inter Science Publication, John Wiley and Sons, New York, pp. 138-142.

Anonymous, 2002, Evaluation of different yeast strains and sweet sorghum genotypes for ethanol and beer production. Annual Report 2002-03, National Research Centre for Sorghum, ICAR, Hyderabad, Andhra Pradesh, pp. 37-38.

Anonymous, 2003, Indian Agriculture 2003, Indian Economic Data Research Centre, New Delhi, p. 120.

Anonymous (2004). By-products and waste utilization (value addition of mango processing waste). Food Digest. 27: 1417.

Arasaratnam, V. And Balasubramaniam, K., 1993, Synergistic action of $\alpha$-amylase and glucoamylase on raw corn. Starch/Starke, 45: 231-233

Arasaratnam, V., Mylvanganam, K. and Balasubramaniam, K., 1998, Corn malt extract for ethanolic and non-ethanolic beverages. Journal of Food Science and Technology, 35(5): 425-427.

Aschengreen N.H. Microbial Enzymes for Ethanol production. Process Biochemistry, August 1969 3pp. (1969).

Ayogu, T. E., 1999, Evaluation of performance of a yeast isolated from Nigerian palm wine in wine production from pineapple fruits. Bio-resource Technology, 69: 189- 190.

Azmi, A.S., Hasan M., Mel, M., 2008. Ethanol Fermentation Technologies from sugar and starch feedstock's. Biotechnology Advances 26, pp. 89105.

AzlinAzmi et al., 2011. frican Journal of Biotechnology Vol. 10(81), pp. 1883318841, 16 December, 2011. Available online at http://www.academicjournals. org/AJB DOI: 10.5897/AJB11.2762 Academic Journals
Banerjee, S. and Kundu. D. (2013) A Comparative Overview of Ethanol Production from Cereal Grains and Potato by Enzymatic Treatment. IJREAT International Journal of Research in Engineering and Advanced Technology, Volume 1.

Batra, L. R. and miller, P. D., 1974, some Asian fermented foods and beverages and associated fungi. Mycologia, 66: 942-950.

Benvides, Q. M., Cabrera, L. J. A. and Zapata, M. L. E., 1985, Preparation of glucose from rice flour by enzymic hydrolysis. Technologia, 26: 9-21.

Beltran G, Rozas N, Mas A, Guillamom J. (2007) Effect of low temperature fermentation on yeast nitrogen metabolism. World J Microbiol Biotechnol 23: 809-815.

Benerji DSN, Ayyanna C, Rajini K, Rao BS, Banerjee DRN, et al., (2010) Studies on physico-chemical and nutritional parameters for the production of ethanol from Mahua flower (Madhuca indica) using Saccharomyces cerevisiae - 3090 through submerged fermentation (smf). J Microbial Biochem Techno 2: 046050. doi:10.4172/1948-5948.1000022

Białas, W., Szymanowska, D. and Grajek, W. 2010. 3131Fuel ethanol production from granular corn starch using Saccharomyces cerevisiae in a long term repeated SSF process with full stillage recycling. Bioresource Technology, 101 (2010) 3126-3128.

Brooks, J. R. and Griffin, V. K., 1987, Liquefaction of rice starch from milled rice flour using heat stable alphaamylase. Journal of Food Science, 52(3): 712-714.

Bugarin, R. B., Alba, D. M. and Del Rosario, E. J., 1987, two stage process of ethanol production from sweet potato flour and rice bran using Aspergillus awamori 
and immobilized yeast. Philippine journal of science, 116(2): 205-217.

Cao, N. J., Krishnan, M. S., Du, j. X., Gong, C. S., Ho, N. W. Y., Chen, Z. D. And Tsao, G. T., 1996, ethanol production from corn cob pretreated by ammonia steeping process using genetically engineered yeast. Biotechnology letters, 18: 1013-1018.

Caputi, A., Ueda, J. M. Brown, T., 1968, Spectrophotometric determination of chromic complex formed during oxidation of ethanol. American journal of ethanol viticulture, 19: 160-165.

Caputi A, Ueda M, Brown T (1968) Spectrophotometric determination of ethanol in wine. Am J Enol Viti 19: 160.

Chaijamrus, S. and Mouthung, B. (2011). Selection of Thai starter components for ethanol production utilizing malted rice from waste paddy. Songklanakarin J. Sci. Technol. 33 (2), 163-170.

Chandrakant, P. and Bisaria, V. S., 2000, simultaneous bio-conversion of glucose and xylose to ethanol by saccharomyces cerevisiae in the presence of xylose isomerase. Applied microbiology and biotechnology, 53: 301-309.

Chen, W. P. and Chang, Y. C., 1984, Production of high fructose rice syrup and high protein rice flour from broken rice. Journal of Science of Food and Agriculture, 35(10): 1128-1135.

Cooking, E. B. And Brown, W., 1969, Structural features of cellulosic materials in relation to enzymatic hydrolysis, cellulose and their application (Ed. Hazory, G. T and Reese, E. T.), American Chemical Society, New York, pp. 152-187.

Coronel, L. M., Velasquez, A. O. and Castillo, M. C., 1981, some factors affecting the production of rice wine using an isolate of Aspergillus oryzae.
Philippine journal of science, 110(1/2): 1-9.

Damir, A. A., 1985, Comparative studies on the physico-chemical properties and microstructure of raw and parboiled rice. Food Chemistry, 16(1): 11-14.

Destexhe A, Peckous L, Picart L: using enzymes in ethanol production. Novozymes a/s 2004.

Dettori-Campus, B. G., Priest, F. G. and Stark, J. R., 1992, Hydrolysis of starch granules by amylase from Bacillus stearothermophilus. NCA 26. Proceedings of Biochemistry, 27: 17-21.

Dominguez, J. M., Cao, N., Gong, C. S. and Tsao, G. T., 1997, Dilute acid hemicellulose hydrolysates from corn cobs for xylitol production by yeast. Biresource Technology, 61: 85-90.

Benerji, D.S.N., Rajini, K., Rao, B.S. (2013). Studies on Physico-Chemical and Nutritional Parameters for the Production of Ethanol from Mahua Flower (Madhuca indica) Using Saccharomyces Cerevisiae - 3090 through Submerged Fermentation (smf). Journal of Microbial \& Biochemical Technology, Volume 2(2): 046-050.

$\mathrm{Du}$ dai, zhiyuan $\mathrm{Hu}$, gengqiang $\mathrm{Pu}, \mathrm{He} \mathrm{Li}$ and Chengto Wang, 2005. Energy efficiency and potential of cassava fuel ethanol in Guangxi region of China, Energy Conversion and management, vol. 47, Issues 13-14 pp 1689-1699

Dung, N. T. P. and Phong, H. X. 2011. Application prospects for the innovation of defined fungal starter in rice wine fermentation. Journal of Life Sciences 5: 255-263.

Dung, N. T. P., Rombouts, F. M. and Nout, M. J. R. 2005. Development of defined mixed-culture fungal fermentation starter granule for controlled production of rice wine. Innovative Food Science and Emerging Technologies 6: 429-441. 
Dung, N. T. P., Rombouts, F. M. and Nout, M. J. R. 2006. Functionality of selected strains of moulds and yeasts from Vietnamese rice wine starters. Food Microbiology 23: 331-340.

Dung, N. T. P., Rombouts, F. M. and Nout, M. J. R. 2007. Characteristics of some traditional Vietnamese starch-based rice wine fermentation starters (men). Food Science and Technology/LWT 40: 130135.

Dung, N. T. P. (2013).Vietnamese rice-based ethanolic beverages. International Food Research Journal 20(3): 1035-1041.

Escalante, L. V., 1999, Litner starch from rice as fat replacer. M. Sc. (Agri.) Thesis, Philippine University Los Banos, College, Laguna, Philippines.

Farid, M. A., El, E. H. A. and El-D, AMN, 2002, Ethanol production from starch by mixed cultures of Aspergillus awamoriand immobilized Saccharomyces cerevisiae at different agitation speeds. Journal of Basic Microbiology, 42(3): 162-171.

Fox, J. D. and Robyt, J. F., 1992, Modification of starch granules by hydrolysis with hydrochloric acid in various ethanols and the formation of new limit dextrins. Carbohydrate Research, 227: 163-170.

Geeta, G. S., Gurumurthy, S. B. and Shankarappa, T. H., 2002, Effect of crude enzymatic hydrolysis of agroresidues on bioethanol production. In: Proceedings of the 43rd Annual Conference of Association of Microbiologists of India, December 1113 held at Haryana Agricultural University, Hisar, India.

Ghosh, A., ChatterjeE, B. and Das, A., 1991, Production of glucoamylase by 2deoxy- D-glucose resistant mutant of Aspergillus terreus 4. Biotechnology Letters, 13(7): 515-520.
Grohmann K, Cameron GR, Buslig SB (1995). Fermentation of sugars in orange peel hydrolisates to ethanol by recombinant $E$. coli KO11. Appl. Biochem. Biotechnol. 51/52: 383-388.

Gokosoyr, J. And Erickson, J., 1980, Celluloses. In: Microbial Enzymes and Bioconversion, Academic Press, London, pp. 283-300.

Hansen, L. P., 1983, The potential of high protein rice flour and its by products to increase the nutritional well-being of young children in rice eating countries. Proceedings of the 6th International Congress of Food Science and Technology, USDA, Agric. Res. Service, Berkeley, KA 94710 USA, 3: 87-88.

Holzapfel, W. H. 1997. use of starter cultures in fermentation on a household scale. Food Control 8: 241-258.

Hodge, J. E. and Hofreiter, B. T., 1962, in: Methods in Carbohydrate Chemistry, Academic Press, New York.

Jackson, M. L., 1973, Soil Chemical Analysis, Prentice Hall of India Private Limited, New Delhi, pp. 181-190.

Jacobus, P. H. and WYK, V., 2001, Biotechnology and the utilization of biowaste as a resource for bioproduct development. Trends in Biotechnology, 19: 172-177.

IJREAT International Journal of Research in Engineering and Advanced Technology, Volume 1, Issue 2, April-May, 2013 ISSN: $2320-8791$

Jiang Yitlong, Shen Jian Fu, Jiang, Y. H. and Shen, J. F., 2002, Study on application of saccharified technology to the brewing technology of waxberry wine. Journal of Zhejiang University Agriculture and Life Science, 28(4): 449-452.

Kahlon, S. S. and Chaudhary, N., 1988, Production of ethanol by 
saccharification of sawdust. Journal of Research, 25: 237-249.

Karakatsanis, A. and Kyriakidis, L. M., 1998, Comparative study of hydrolysis of various starches by alpha-amylase and glucoamylase in PEG-dextran and PEGsubstrate aqueous two phase systems. Starch/Starke, 50(8): 349-353.

Karakatsanis, A., Kyriakidis, L. M. and Stamatoudis, M., 1997, Hydrolysis of various starches by synergistic action of alpha-amylase and glucoamylase aqueous two phase impeller agitated systems. Starch/Starke, 49(5): 194- 199.

Kajiwara, S., Aritomi, T., Suga, K., Ohtaguchi, K. and Kobayashi, O., 1999, Over expression of the ole-1 gene enhances ethanol fermentation by Saccharomyces cerevisiae. Applied Microbiology and Biotechnology, 50:568-573.

Keating, L., Kelly, C. and Fogarty, W., 1998, Mechanism of action and the substrate dependent $\mathrm{pH}$ maximum shift of alphaamylase of Bacillus coagulans. Carbohydrate Research, 309(4): 311318.

Khong, K. V., 1981, Biochemical characteristics of traditional Vietnamese rice wine. Izvestiya Vysshikh Uchebnykh Zavedenii, Pischevaya Technologiya, 4: 26- 29.

Kundu, B. S., Bardiya, M. C., Daulta, B. S. and Tauro, P., 1980, Evaluation of exotic grapes grown in Haryana for white table wines. Journal of Food Science and Technology, 17(5): 221224.

Lancaster, E. B., Moulton, K. J., UHL, D. and Sohns, V. E., 1964, Modification of cereal flours with hydrochloric acid. Cereal Chemistry, 41: 484-492.

Lebaka Veeranjaneya Reddy, Obulam Vijaya Sarathi Reddy and Young-Jung Wee. Department of Microbiology, Yogi Vemana University, Kadapa (A.P.)
516003, India. 2. Department of Biochemistry, Sri Venkateswara University, Tirupati 517502, India. 3. Department of Food Science and Technology, Yeungnam University, Gyeongsan, Gyeongbuk 712-749, Korea. Accepted 4 April, 2011

Lebeau, T., Jouenne, J. and Junter, G. A., 1997, Continuous ethanolic fermentation of glucose xylose mixtures by co-immobilized Saccharomyces cerevisiae and Candida shehatae. Applied Microbiology and Biotechnology, 50: 309-313.

Lakhawat, S.S., Aseri, G.K. and Gaur, V.S. (2011). Comparative study of ethanol production using yeast and fruits of Vitis lanataroxb. International Journal of Advanced Biotechnology and Research, ISSN 0976-2612, pp 269277.

Lewis, S. M. Fermentation ethanol. in Industrial Enzymology. (Ed. Tony Godfrey \& Stuart West), Macmillan Publishers Ltd., England, (1996).

Lee, S. Y., Shin, Y. C., Lee, S. H., Park, S. S., Kim, H. S. and Byun, S. M., 1984, Saccharification of uncooked starch. Korean Journal of Food Science and Technology, 16(4): 463-471.

Lee, Y. Y., WU, Z. AND TORGET, R., 2000, Modeling of counter current shrinking bedreactorin dilute acid total hydrolysis of lignocellulosic biomass. Bioresource Technology, 71: 29-39.

Lyons, T. P ethanol - Power/Fuel. in Industrial Enzymology. (Ed. Tony Godfrey \& Jon Reichelt), Macmillan Publishers Ltd., England, (1983).

Madhukara K, Krishnanad N, Srilatha HR (1993). Ensilage of mango peel for methane generation. Process Biochem., 28: 119-123.

Mendoza, B. C. and Raymundo, A. K., 1990, Optimization of batch ethanol production by Philippine isolate of 
Zymomonas mobilis using molasses as substrate. Philippine Journal of Biotechnology, 1: 124-137.

Miller G.L., 1959, Use of dinitrosalicylic acid reagent for determination of reducing sugar. ANnals Chemistry, 31:426-428.

Maarel, M., Veen, B., Uitdehaag, J. C. M., Leemhuis, H. and Dijkhuizen, L., 2002, Properties and applications of starch converting enzymes of the $\alpha$-amylase family. Journal of Biotechnology, 94(2): 137-155.

Nebesny, E., Rosicka, J. and Pierzgalski, T., 1998, Enzymatic hydrolysis of wheat starch into glucose. Starch/Starke, 50(8): 337-341.

Ndip, R. N., Akoachere, J.-F. K. T., Dopgima, L. L. and Ndip, L. M. 2001. Characterization of yeast strains for wine production. Applied Biochemistry and Biotechnology 95: 209-220

Neerupudi K.B., Kesavapillai,B., Tammana R.R. and Gudapaty, S.R. (2013) Ethanol Production Potential of Locally Isolated Yeast Strain from Toddy Sap by Using Cassava Waste. Research Journal of Pharmaceutical, Biological and Chemical Sciences, ISSN: 0975-8585

Nimbkar, N. T., Ghanekar, A. R. and Joseph, R. D., 1989, Development of improved cultivars and management practices in sweet sorghum as a source of ethanol. In: Technology and Application of Alternative Uses of Sorghum (Ed. Ingle, V. M., Kulkarni, D. N. and Thorat, S. S.), National Seminar, 2-3 February, held at Marathwada Agricultural University, Parbhani, pp. 180-188.

Palaniveloo, K. and Vairappan, C.V. 2013. Biochemical properties of rice wine produced from three different starter cultures. Journal of tropical biology and conservation 10: 31-41.

Park, K. I., Mheen, T. I., Lee, L. H., Chang, C. H., Lee, S. R. and Kwon T. W., 1977, Korean yakju and takju.
Symposium on Indigenous Fermented Foods, Bangkok, Thailand.

Reddy, L.V., Reddy, O.V.S. and Wee, Y.G. (2011).Production of ethanol from mango (Mangifera indica L.) peel by Saccharomyces cerevisiae CFTRI101. African Journal of Biotechnology, Vol. 10(20), pp. 4183-4189.

Ramarathnam, N. and Kulkarni, P. R., 1988, Chemical composition and cooking quality of rice varieties grown in Maharashtra. Journal of Maharashtra Agricultural Universities, 13: 203-205.

Sanchez, O.J., Cardona, C.A., 2008. Trends in biotechnological production of fuel ethanol from different feed stocks. Bioresour. Technol. 99, 5270-5295.

Sanchez, C. P., Juliano, B. O., Laude, V. T. and Perez, C. M., 1987, Non-waxy rice For tapuy (rice wine) production. Cereal Chemistry, 65(3): 240-243.

Sadhana Singh, Dhaliwal, Y. S., Nagi, H. P. and Kalia, M., 1998, Quality characteristics of six rice varieties of Himachal Pradesh. Journal of Food Science and Technology, 35: 74-78.

Sarikaya, E., Higasa, T., Adachi, M., Mikami, B., 2000. Comparison of degradation abilities of [alpha]- and [beta]-amylases on raw starch granules. Process Biochem. 35, 711-715.

Saucedo, V. M. and Karim, M. N., 1996, a decreasing feeding profile for the optimizationof ethanol production in a recombinant Escherichia coli fed batchfermentation. Biotechnology Letters, 18: 1055-1060.

Shariffa, Y.N., Karim, A.A., Fazilah, A., Zaidul, I.S.M., 2009. Enzymatic hydrolysis of granular native and mildly heat-treated tapioca and sweet potato starches at sub-gelatinization temperature. Food Hydrocolloids 23, 434-440. Fuel ethanol production from granular corn starch using Saccharomyces cerevisiae in a long 
term repeated SSF process with full stillage recycling.

Sattler, W., Glatter, O. and Steiner, W., 1998, Effect of enzyme concentration on the rate of hydrolysis of cellulose. Biotechnology and Bioengineering, 33: 1221-1234.

Satyanarayana, T., Noorwez, S. M., Kumar, S., Rao, J. L. U. M., Ezhilvannan, M., Kaur, P. and Littlechild, J., 2004, Development of an ideal starch saccharification process using amylolytic enzymes from thermophiles. Biochemical Society Transactions, 32(2): 276-278.

Sharma, S., Pandey, M. and Saharan, B., 2002, Fermentation of starch to ethanol by an amylolytic yeast Saccharomyces cerevisiae SJ-31. Indian Journal of Experimental Biology, 40: 325-328.

Shiva, C. A., Hamdapurkar, S. K. and Walkte, P. S., 2001, a study on biochemical conversion of agricultural starchy wastes into glucose syrup. In: Proceedings of the 42 Annual Conference of Association of Microbiologists of India, held at Gulbarga University, November 9-11, p. 72.

Singh, A. and Jain, V. K., 1994, Fermentation kinetics of Zymomonas mobilison sucrose and other substrates, a comparative study. Indian Journal of Microbiology, 34: 205-212.

Slominska, L., Klisowska, M. and Grzeskowiak, A., 2003, Degradation of starch granules by amylases. Journal of Food Science and Technology, 6(2): 321- 323.

Suchi Srivastava, Modi, D. R. and Garg, S. K., 1997, Production of ethanol from guava pulp by yeast strains. Bioresource Technology, 60: 263-265.

Suresh, K., Kiransree, N. and Venkateshwar Rao, L., 1999, utilization of damaged sorghum and rice grains for ethanol production by simultaneous saccharification and fermentation.

Thakur, S., Shrivastava, B., Ingale, S., Kuhad, R.C. and Gupte, A. (2013). Degradation and selective ligninolysis of wheat straw and banana stem for an efficient bioethanol production using fungal and chemical pretreatment, Biotech 3:365372.

Tao, C., 1983, The making of China's oldest wine. Brewing and Distilling International, 13(6): 33-34.

Teramoto, Y., Okamoto, K., Kayashima, S. and Ueda, S., 1993, Rice wine brewing with sprouting rice and barley malt. Journal of Fermentation and Bioengineering, 75: 460-462.

Teramoto, Y., Okamoto, K., Ueda, S. and Kayashima, S., 1993, Rice wine brewing with sprouting rice, sprouting rice infected with Aspergillus oryzae and rice koji. Journal of Institute of Brewing, 99(6): 467-471.

Wang, J. Z., Shen, J. Y., Xie, X. S. and Liu, M. F., 1999, Analysis of rice quality and wine indicators of some high glutinous rice varieties for wine making. Zhejiang- Nongye-Kexue, 2: 77-78.

Wojciech Białas, Daria Szymanowska, Włodzimierz Grajek 101 (2010) 31263131 Borbála Erdei, Zsolt Barta, Bálint Sipos, Kati Réczey, Mats Galbe and Guido Zacchi REetseharachnol production from mixtures of wheat straw and wheat meal Erdei et al., Biotechnology for Biofuels 2010, 3:16

Wyman CE (1996). Handbook on Ethanol: Production and Utilization. Taylor \& Francis, Bristol, Paris, France.

Yadav P, Garg N, Diwedi DH (2009) Effect of location of cultivar, Fermentation temperature and additives in the physicchemical and sensory qualities on mahua (Madhuca indicaJ.F.Gmel) wine Preparation. Natural product radiance 8: 406-418. 
Yamadaa, R., Yamakawaa, S., Tanakab, T., Oginoa, C., Fukudab, R., Akihiko Kondoa. (2011). Direct and efficient ethanol production from high-yielding rice using a Saccharomyces cerevisiae strain that express amylases. Enzyme and Microbial Technology.

Zhang X., 1982, Production of Fangshaojiu (rice wine) using improved kojimaking and yeast culture. Food and Fermentation Industries No. 1, pp. 3239.

Demirbas, A. (2009). "Political, economic and environmental impacts of biofuels: A review." Applied energy86: S108-S117.
Inlow, D., et al., (1988). "Fermentation of corn starch to ethanol with genetically engineered yeast." Biotechnology and bioengineering32(2): 227-234.

Sims, R. E., et al., (2010). "An overview of second generation biofuel technologies." Bioresource technology 101(6): 1570-1580.

Spyridon, A., et al., (2016). "Consolidated briefing of biochemical ethanol production from lignocellulosic biomass." Electronic Journal of Biotechnology 19(5): 44-53.

\section{How to cite this article:}

Suryawanshi, O.P., D. Khokhar and Patel, S. 2018. Effect of Different Pre-Treatment Methods on Reducing Sugar of Rice Substrate to Enhance the Ethanol Yield. Int.J.Curr.Microbiol.App.Sci. 7(03): 2715-2733. doi: https://doi.org/10.20546/ijcmas.2018.703.314 